\title{
Characterization of a mutant rat kangaroo cell line with alterations in the cell cycle and DNA repair
}

\author{
E.N. Miyaji ${ }^{1}$, R.T. Johnson ${ }^{3}$, C.S. Downes ${ }^{3}$, E. Eveno ${ }^{4}$, M. Mezzina ${ }^{4}$, A. Sarasin ${ }^{4}$ and C.F.M. Menck ${ }^{2}$
}

\begin{abstract}
Using a positive selection system for isolating DNA replication and repair related mutants, we isolated a clone from a rat kangaroo cell line (PtK2) that has increased sensitivity to UV light. Characterization of this clone indicated normal post-replication repair after UV irradiation, and normal removal rates of cyclobutane pyrimidine dimers and pyrimidine(6-4)pyrimidone photoproducts by excision repair. However, this cell line has decreased ability to make early incisions on damaged DNA, possibly indicating a defect in preferential repair of actively transcribed genes, and a slower cell proliferation rate, including a longer S-phase. This phenotype reinforces the present notion that control of key mechanisms in cell metabolism, such as cell cycle control, repair, transcription and cell death, can be linked.
\end{abstract}

\section{INTRODUCTION}

Isolation of DNA repair mutants from normal culture cells has proven to be very useful in identifying genes related to cell genome stability maintenance (Collins, 1993). These mutants have been useful in further understanding the several mechanisms that cells use to cope with DNA damage, mainly through removal by classic nucleotide excision repair. Simple damage removal is also related to other metabolic pathways, including DNA replication, RNA transcription and cell cycle (Seroz et al., 1995).

A photoreactivation prone cell line (PtK2) from the marsupial Potorous tridactylus (Chiang and Rupert, 1979), is useful for isolating mutants defective in processing ultraviolet (UV)-induced DNA damage, with a positive selection system similar to that described by Rosenstein and Ohlsson-Wilhelm (1979) in ICR 2A frog cells. This system uses cell ability to eliminate cyclobutane pyrimidine dimers (CPD) enzymatically through exposure to light (300-500 $\mathrm{nm}$ ) by photoreactivation, to rescue mutant cells unable to process DNA damages by incorporating the photosensitizer nucleotide analogue 5-bromo-2'-deoxyuridine (BUdr). Briefly, cells are irradiated with UV, followed by incubation with BUdr and exposure to black light (310-400 nm), leading to both CPD photoreactivation and mortality of those cells that had incorporated BUdr. Cells surviving this selection procedure, most probably because of failure in replication of damaged templates or DNA repair replication, and consequent failure in BUdr incorporation, can be isolated. Based on this selection system, we were able to isolate a clone with a slight increase in
UV sensitivity. A detailed characterization of this clone concerning nucleotide excision and post-replication repair was made and is described below.

\section{MATERIAL AND METHODS}

\section{Cell culture}

The PtK2 cell line is derived from the kidney of a male rat kangaroo (Potorous tridactylus), kindly supplied by Dr. C.S. Rupert (University of Texas, USA). The cells were routinely grown at $37^{\circ} \mathrm{C}$ in a $5 \% \mathrm{CO}_{2}$ atmosphere in Dulbecco's modified Eagle's medium supplemented with $10 \%$ calf serum and antibiotics.

\section{UV-irradiation and photoreactivation}

The cells were washed twice with prewarmed PBS and irradiated with a low-pressure germicidal lamp (254 $\mathrm{nm}$, dose rate $0.5 \mathrm{~J} \mathrm{~m}^{-2} \mathrm{~s}^{-1}$ ). Photoreactivation was done in PBS with cell plates spread in a single layer over fluorescent (2-15 W) or black light lamps (310-400 nm), separated from the dishes by a 4-mm glass. Cells were exposed to this light for $2 \mathrm{~h}$ at $37^{\circ} \mathrm{C}$. After irradiation and photoreactivation, PBS was replaced with normal growth medium.

\section{Selection procedure}

Exponentially growing cells were irradiated with UV $\left(15 \mathrm{~J} / \mathrm{m}^{2}\right)$ and after incubation in complete medium for $1 \mathrm{~h}$ at $37^{\circ} \mathrm{C}$ to allow the replicating regions to reach the lesions, $3.3 \times 10^{-5} \mathrm{M}$ BUdr and $2.5 \times 10^{-6} \mathrm{M}$ 5-fluoro-2' deoxyuridine

${ }^{1}$ Departamento de Biologia, Instituto de Biociências and ${ }^{2}$ Departamento de Microbiologia, Instituto de Ciências Biomédicas, USP, São Paulo, SP, Brasil. Send correspondence to C.F.M.M. Av. Prof. Lineu Prestes, 1374,05508-900 São Paulo, SP, Brasil. E-mail: cfmmenck@usp.br ${ }^{3}$ CRC Mammalian Cell DNA Repair Research Group, Department of Zoology, University of Cambridge, UK.

${ }^{4}$ Laboratory of Molecular Mutagenesis, UPR 42, Institut Fédératif CNRS, IFC1- Institut de Recherches Scientifiques sur le Cancer, Villejuif, France. 
(FUdr) were added to the medium. Cells were cultivated for more $24 \mathrm{~h}$ and then exposed to black light for $2 \mathrm{~h}$. This protocol was repeated again after 14 days.

\section{Cell survival}

The cells were plated on small Petri dishes $\left(24 \mathrm{~cm}^{2}\right)$ at low density $\left(10^{3}\right.$ cells per plate). After 14 days, they were fixed with $10 \%$ formaldehyde and stained with $1 \%$ crystal violet. Colonies of more than 20 cells were scored. Survival values correspond to the ratio between the number of treated cell colonies and the number of non-irradiated cell colonies.

\section{BNDC post-replication repair assay}

Exponentially growing cells were UV-irradiated and incubated in fresh medium for $1 \mathrm{~h}$ before labeling with ${ }^{3} \mathrm{H}$-thymidine $(20 \mu \mathrm{Ci} / \mathrm{ml})$ for $15 \mathrm{~min}$. Cells were then removed for immediate analysis or cultivated in medium containing $10^{-5} \mathrm{MdNTPs}$ before analysis. DNA extraction and BNDC (benzoylated naphtylated diethyl cellulose chromatography) were performed as described by Pillidge et al. (1986).

Assay for incisions by hydroxyapatite (HAP) chromatography

The incision assay was based on the method described by Squires et al. (1982). Briefly, cells were incubated for $72 \mathrm{~h}$ with ${ }^{3} \mathrm{H}$-thymidine $(0.2 \mu \mathrm{Ci} / \mathrm{ml})$ in growth medium to prelabel the DNA, replated in fresh medium and further incubated for $24 \mathrm{~h}$. The DNA synthesis inhibitor hydroxyurea $\left(\mathrm{HU}, 10^{-2} \mathrm{M}\right)$ and (1- $\beta$-D-arabinofuranosyl)cytosine $\left(\operatorname{araC}, 10^{-4} \mathrm{M}\right)$ were added to the medium, either before and after UV-irradiation or in pulses after irradiation. Repair ended by washing the cells with ice-cold PBS and lysing them for $25 \mathrm{~min}$ on ice in an alkaline DNA-unwinding buffer $(0.15 \mathrm{M} \mathrm{NaOH}, 0.3 \mathrm{M} \mathrm{NaCl}$ and $0.01 \mathrm{M}$ EDTA in $5 \%$ sucrose). After neutralization with $0.15 \mathrm{M} \mathrm{KH}_{2} \mathrm{PO}_{4}$, DNA size was reduced by sonication for $8 \mathrm{~s}$ at $24 \mathrm{kHz}$, and at a 8 - $\mu \mathrm{m}$ amplitude. Hydroxyapatite column chromatography and DNA break calibration were carried out as described by Squires et al. (1982).

\section{Measurements of UV-endonuclease- sensitive sites (ESS)}

The number of ESSs was determined essentially as described by Menck and Meneghini (1982). Basically, purified DNA was incubated with a Micrococcus luteus extract with UV-endonuclease activity. Untreated and treated DNA molecular weights were measured by alkaline sucrose gradient sedimentation. From these two values, ESS frequency, taken as CPD frequency per unit length of DNA, was calculated.
Determination of pyrimidine (6-4) pyrimidone photoproducts ((6-4)PPs) by immuno-slot-blots

For immuno-slot-blot analysis, $0.5 \mu \mathrm{g}$ purified DNA was loaded on nitrocellulose membrane (BA 83-S, Schleicher \& Schuell). Membranes were saturated with PBS containing 5\% lyophilized no-fat milk (nfm) for $1 \mathrm{~h}$ at $37^{\circ} \mathrm{C}$ (or several hours at $4^{\circ} \mathrm{C}$ ), and then incubated with 64-2 antibodies (diluted 1:500 in 0.5\% nfm PBS) for $1 \mathrm{~h}$ at $37^{\circ} \mathrm{C}$ (Mezzina et al., 1994). After extensive washing with this buffer, blots were incubated with a 1:2000 dilution of a second anti-mouse horseradish peroxidase-conjugated antibody (Calbag, San Francisco, USA) for $30 \mathrm{~min}$ at room temperature. Blots were then extensively washed with $0.5 \% \mathrm{nfm}$ PBS and PBS before processing with ECL (Amersham) solutions and exposure of X-ray films. For precise (6-4)PPs quantification, films of different exposure times were scanned in order to calculate absorbance values in a linear range.

\section{Synchronization}

After reaching confluence, cells were cultivated for another 10 days to make sure all had attained a pre-replicative $\mathrm{G}_{0}$ state, then plated at a lower density in normal growth medium with aphidicolin, a DNA synthesis inhibitor. After $24 \mathrm{~h}$, with the cells synchronized at early S-phase, the aphidicolin-containing medium was replaced by normal growth medium, followed by immediate initiation of DNA replication. Pulse labeling was performed by adding ${ }^{3} \mathrm{H}$-thymidine $(2 \mu \mathrm{Ci} / \mathrm{ml}$, Amersham) to the culture medium for $30 \mathrm{~min}$. The incorporated radioactivity was measured (Menck and Meneghini, 1982).

\section{RESULTS}

A positive selection procedure for isolating cell mutants potentially affected in their ability to process DNA damage was tested. Basically, the cells were UV-irradiated and, after an incubation period in normal medium, cultivated in the presence of BUdr. Hypothetically, replication machinery would stall at DNA lesions but translesion synthesis would subsequently allow replication continuation, leading to BUdr incorporation. Alternatively, cells efficiently eliminating lesions by DNA repair would also incorporate BUdr during repair replication. Since PtK2 cells have efficient photoreactivation repair, exposure to black light $24 \mathrm{~h}$ after UV irradiation would remove CPDs. Black light would also kill normal cells efficiently incorporating BUdr. We would expect, therefore, that cells unable to perform translesion synthesis or with DNA repair defects would be more likely to survive. After two selection procedure cycles, 17 colonies were obtained and tested for UV sensitivity. Of these, 11 clones were no different from parental cell line; three, more resistant to $\mathrm{UV}$, and the remainder slightly more UV sensitive. The fact that we obtained clones resistant to 
UV was also expected, since the positive selection used can favor cells with increased ability to deal with DNA damage. One of the sensitive clones, M2.7.1, was chosen for further analysis. M2.7.1 cells were slightly more sensitive to UV and exposure to photoreactivating light $24 \mathrm{~h}$ after irradiation caused a cell survival increase (Figure 1), which was not observed in wild-type cells. Differences in survival between wild-type and M2.7.1 cells irradiated with 7.5 and $15 \mathrm{~J} / \mathrm{m}^{2}$ were significant $(\mathrm{P}<0.05$, Student $t$-test $)$, while differences between survival in cells maintained in the dark or exposed to photoreactivating light were only significant in M2.7.1 cells $(\mathrm{P}<0.01$, Student $t$-test). We previously determined that although wild-type cells are still able to eliminate CPDs $24 \mathrm{~h}$ after irradiation, there is no increase in survival (Miyaji and Menck, 1995) and that this probably happens due to irreversible events in the apoptosis pathway that have already taken place by this time (Miyaji and Menck, 1996).

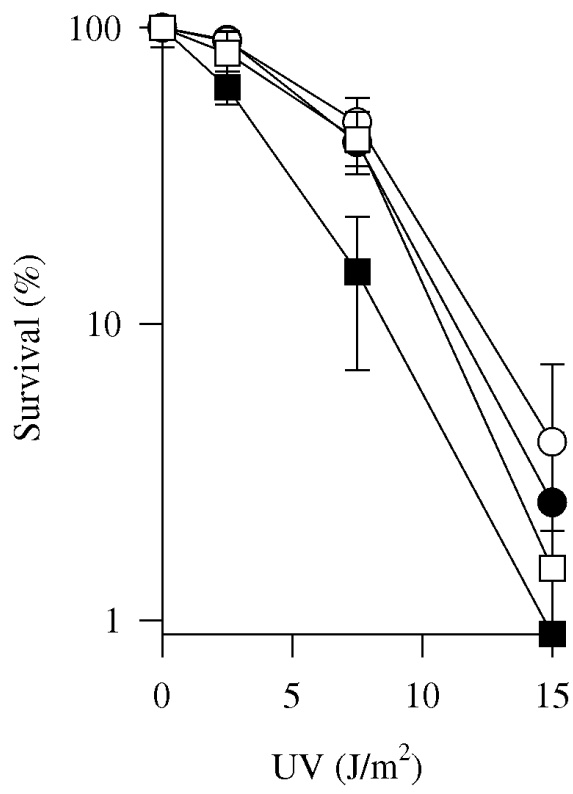

PtK2-wt dark after $24 \mathrm{~h}$

PtK2-wt PRL after $24 \mathrm{~h}$

M2.7.1 dark after $24 \mathrm{~h}$

M2.7.1 PRL after $24 \mathrm{~h}$

Figure 1 - UV survival of the M2.7.1 mutant. PtK2 parental cell line (circles) and M2.7.1 (squares) cells were irradiated with UV, maintained in the dark for $24 \mathrm{~h}$, then exposed (open symbols) or not (closed symbols) to photoreactivating light (PRL). Clones were scored for cell survival 14 days after plating. wt, Wild-type cells.
Nascent chain elongation analysis was performed by BNDC chromatography, a technique that allows determination of the percentage of newly synthesized double-stranded DNA, which corresponds to the rate of DNA chain elongation growth after a given treatment (Pillidge et al., 1986). No difference was found between growth of daughter strands from M2.7.1 and wild-type cells irradiated with different UV doses (Figure 2A). The same analysis was performed after longer periods following UV irradiation and, again, no difference was detected between M2.7.1 and wild-type cells (Figure 2B and C). This indicates that there is no defect in mutant ability to elongate newly synthesized DNA in the presence of a damaged template, i.e., translesion synthesis is normal in M2.7.1.

We next assayed M2.7.1 excision repair capacity by quantifying breaks induced by the incision step of the DNA excision repair pathway. This was performed by HAP chromatography (Squires et al., 1982). Analysis after irradiation with different UV doses indicated a significant decrease in the number of single-strand breaks generated in M2.7.1 when compared to wild-type cells $(\mathrm{P}<0.01$, Student $t$-test) (Figure 3A). Analysis at increased periods after irradiation further confirmed this decrease in M2.7.1 incision activity rate, at least until $6 \mathrm{~h}$ after irradiation (Figure 3B). Although these results indicate a DNA excision repair defect, quantification of CPDs (ESS) and (64)PPs (Table I), did not indicate any gross difference between M2.7.1 and wild-type cells in the removal of these lesions $24 \mathrm{~h}$ after UV exposure. Clearly, very few (if any) CPDs are eliminated in the dark by wild-type and M2.7.1 cells, while (6-4)PPs were not detected after this period of time. Moreover, these cells seem to be equally efficient in the removal of CPDs when illuminated with photoreactivating light. Interestingly, the data indicate that the cells are also able to remove (6-4)PPs by exposure to photoreactivating light.

Alterations in pool precursors for the DNA synthesis could, in principle, also be responsible for the altered M2.7.1 cell phenotype. However, this seems unlikely, since no defect in sealing DNA breaks after UV-irradiation was noticed either in mutant or wild-type cells and no differences in M2.7.1 cell phenotype were observed when deoxynucleotides were supplemented in the cell media (data not shown).

We investigated M2.7.1 and wild-type cell proliferation. A slower growth rate was found for M2.7.1, when compared to wild type cells (Figure 4A). Moreover, after release of both from early S-phase arrest and subsequent DNA synthesis analysis, there was a longer S-phase of approximately $15 \mathrm{~h}$ in M2.7.1 compared to $9 \mathrm{~h}$ in parental cells (Figure 4B).

\section{DISCUSSION}

A positive selection procedure was used to obtain cell mutants defective in DNA damage processing after UV ir- 
A

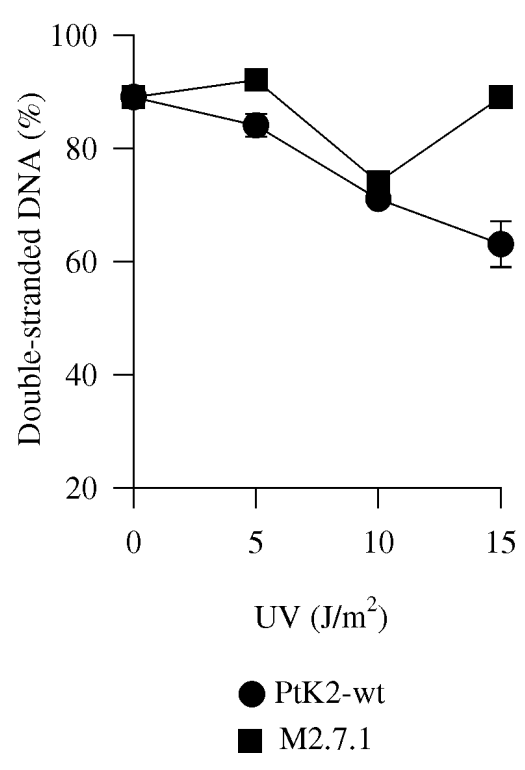

B

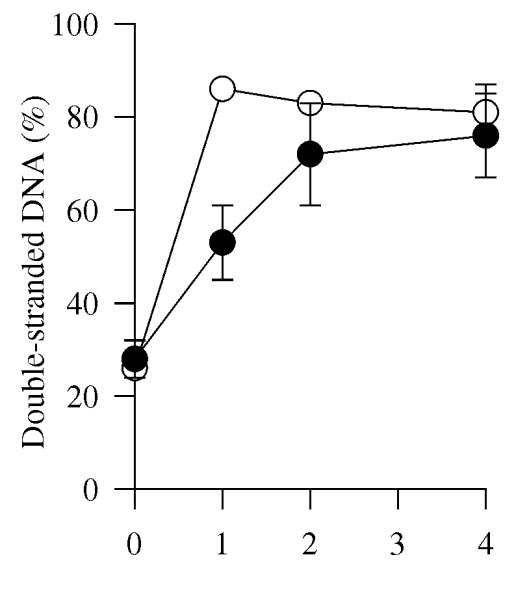

Time (h)

$$
\begin{aligned}
& \bigcirc \text { PtK2-wt UV }=0 \mathrm{~J} / \mathrm{m}^{2} \\
& \text { PtK2-wt UV }=5 \mathrm{~J} / \mathrm{m}^{2}
\end{aligned}
$$

C

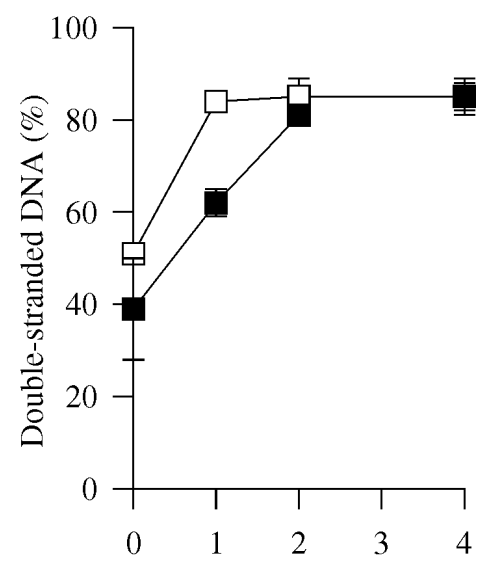

Time (h)

Figure 2 - Determination of nascent chain elongation. PtK2 (circles) and M2.7.1 (squares) cells were irradiated with indicated UV doses, maintained in their original medium for $1 \mathrm{~h}$, then incubated with ${ }^{3} \mathrm{H}$-thymidine. Cells were then incubated for $3 \mathrm{~h}$ or for the time indicated in fresh medium with dNTPs and prepared for BNDC-chromatography. A: UV dose response; B: PtK2 time course - $0 \mathrm{~J} / \mathrm{m}^{2}$ (open circles) and $5 \mathrm{~J} / \mathrm{m}^{2}$ (closed circles); C: M2.7.1 time course - $0 \mathrm{~J} / \mathrm{m}^{2}$ (open squares) and $5 \mathrm{~J} / \mathrm{m}^{2}$ (closed squares). wt, Wild-type cells.
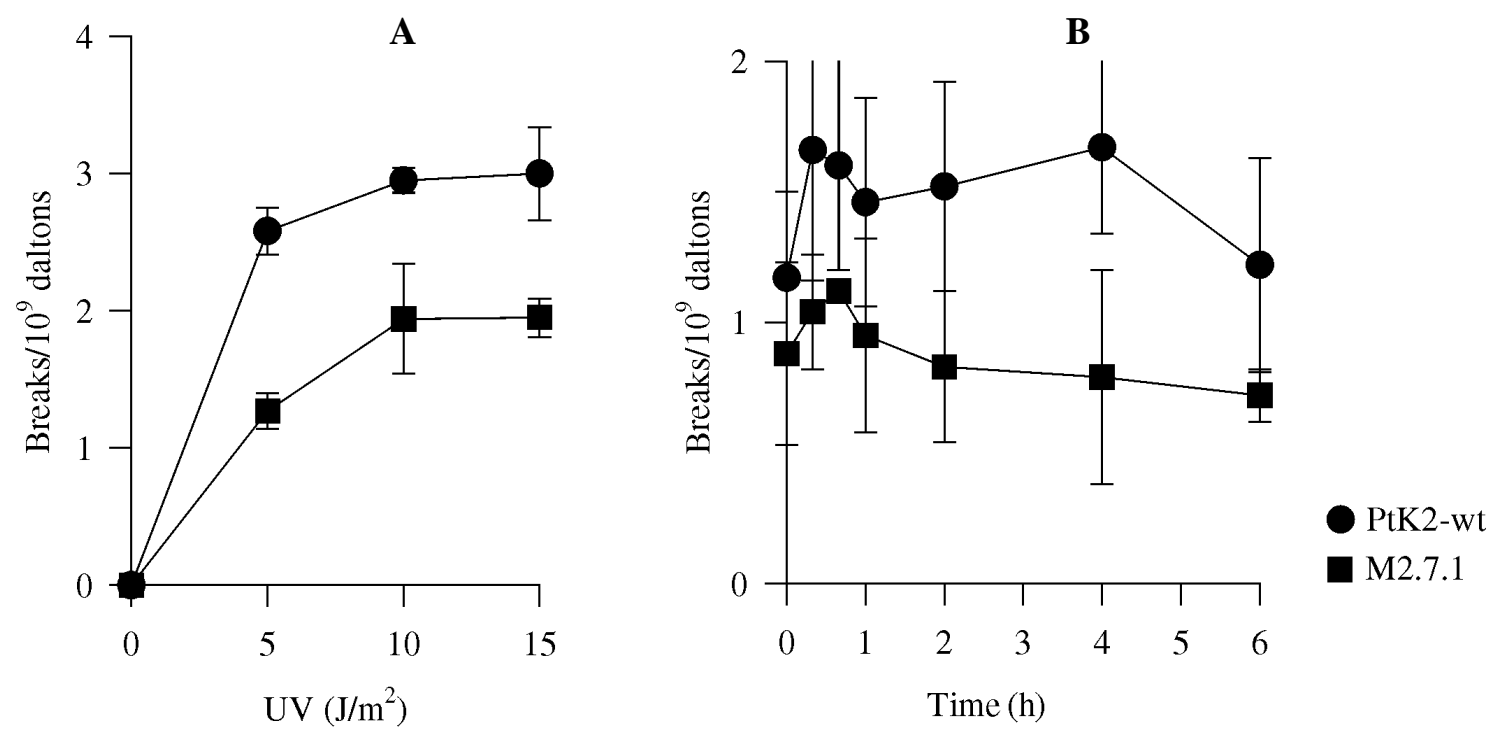

Figure 3 - DNA repair measurements by incision assay. A: UV dose response. PtK2 (circles) and M2.7.1 (squares) cells labeled with ${ }^{3} \mathrm{H}$-thymidine were incubated for $40 \mathrm{~min}$ with $\mathrm{HU}$ and araC, irradiated with indicated UV doses, incubated with inhibitors for another 40 min and then prepared for HAP chromatography. B: PtK2 (circles) and M2.7.1 (squares) cells labeled with ${ }^{3} \mathrm{H}$-thymidine were irradiated with $\mathrm{UV}\left(5 \mathrm{~J} / \mathrm{m}^{2}\right)$, incubated in fresh medium for indicated time before incubation for $40 \mathrm{~min}$ with $\mathrm{HU}$ and araC and then prepared for HAP chromatography. wt, Wild-type cells.

radiation. We characterized one clone with increased UV sensitivity. These cells have normal DNA chain elongation in the presence of UV-induced lesions. Thus, it is unlikely that post-replication repair mechanisms in these cells are affected. On the other hand, we found that they have a significant defect in overall DNA excision repair measured shortly after UV exposure, as incisions accumulated at a lower frequency than in the parental cells. Moreover, these mutants had decreased cell-growth rate and corresponding increased S-phase length.

PtK2 cells did not eliminate CPDs efficiently (less than $10 \%$ of CPDs are removed in $24 \mathrm{~h}$ ) (Miyaji and Menck, 
1995 and the present work). However, (6-4)PPs photoproducts were reversed efficiently with no lesions detected after $24 \mathrm{~h}$ in the dark. The M2.7.1 clone did not show any significant difference in (6-4)PPs removal when compared to parental cells $24 \mathrm{~h}$ after irradiation. But initial (6-4)PPs removal rates could be lower than normal during the first few hours after UV in M2.7.1. Alternatively, PtK2 cells may efficiently do preferential repair of CPDs or (6-4)PPs photoproducts in actively transcribed genes, as do rodent cells (Bohr et al., 1986). The number of incisions accumulated in these cells is small compared to human cells (about 20\% incisions determined for normal human cells) (Squires et al., 1982), possibly reflecting actively transcribed gene repair. If this hypothesis is correct, mutant cells could have

Table I - DNA repair of CPDs

(ESS) and (6-4)PPs in PtK2 (wt) and M2.7.1 cells.

\begin{tabular}{|lccccc|}
\hline Treatment $^{\mathrm{a}}$ & \multicolumn{2}{c}{$\% \mathrm{ESS}^{\mathrm{b}}$} & & \multicolumn{2}{c|}{$\%(6-4) \mathrm{PPs}^{\mathrm{b}}$} \\
\cline { 2 - 3 } \cline { 6 - 7 } \cline { 6 - 7 } & wtPtK2 & M2.7.1 & & wtPtK2 & M2.7.1 \\
\hline $\mathrm{UV}=15 \mathrm{~J} / \mathrm{m}^{2} \mathrm{t}=0 \mathrm{~h}$, dark & 100 & 100 & & 100 & 100 \\
$\mathrm{UV}=15 \mathrm{~J} / \mathrm{m}^{2} \mathrm{t}=0$ h, PRL & $35 \pm 3$ & $55 \pm 9$ & & $56 \pm 15$ & $35 \pm 24$ \\
$\mathrm{UV}=15 \mathrm{~J} / \mathrm{m}^{2} \mathrm{t}=24 \mathrm{~h}$, dark & $99 \pm 14$ & $78 \pm 3$ & & $\mathrm{ND}^{\mathrm{c}}$ & $\mathrm{ND}$ \\
$\mathrm{UV}=15 \mathrm{~J} / \mathrm{m}^{2} \mathrm{t}=24 \mathrm{~h}, \mathrm{PRL}$ & $40 \pm 22$ & $39 \pm 7$ & & $\mathrm{ND}$ & $\mathrm{ND}$ \\
\hline
\end{tabular}

The values represent the average from at least three independent experi-

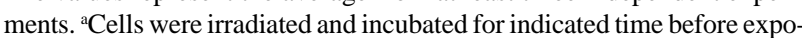
sure to photoreactivating light (PRL) or maintenance in the dark for $2 \mathrm{~h}$ in

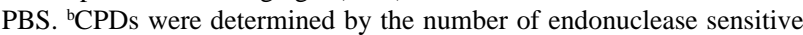
sites (ESS) and pyrimidine (6-4) pyrimidone photoproducts ((6-4)PPs) by immuno detection. ${ }^{\mathrm{N} D}=$ Not detected a diminished incision capacity for preferential repair of active genes. Increased UV sensitivity in these cells would be explained by this defect since preferential repair likely has an important function in cell resistance to UV (Bohr $e t$ al., 1986).

The slower M2.7.1 growth rate indicates problems in cell cycle control in these cells. Much evidence points to a direct relationship between cell cycle control and DNA damage responses. It is well known that eukaryotic cells arrest their cell cycle at G1, S or G2 phases after DNA damage, a response known as checkpoint control (Hunter, 1993). These delays would allow the cell to cope with lesions before proceeding to a subsequent cell cycle phase. If the cells cannot tolerate the lesions, they may initiate a cascade of events leading to cell death through apoptosis (Steller, 1995). We have shown that most PtK2 cells die through apoptosis (Miyaji and Menck, 1996, 1998). Growth rate defect, including the increased S-phase duration observed in M2.7.1 cells, may interfere with cell ability to choose between interrupting the cell cycle or initiating apoptosis in response to DNA damage. Such a defect may also be directly related to the selection procedure used, since less BUdr would be incorporated after irradiation of such cells, a possibility consistent with the observed increase in survival when cells are photoreactivated $24 \mathrm{~h}$ after UV irradiation, a feature not found in the parental cells (Miyaji and Menck, 1995 and the present work). Significant differences in apoptosis induction (analyzed by induction of internucleosomal DNA breaks) in M2.7.1 were not detected (data not shown).

The PtK2 cells (both parental and mutant cell lines) could eliminate (6-4)PPs faster when illuminated by pho-
A

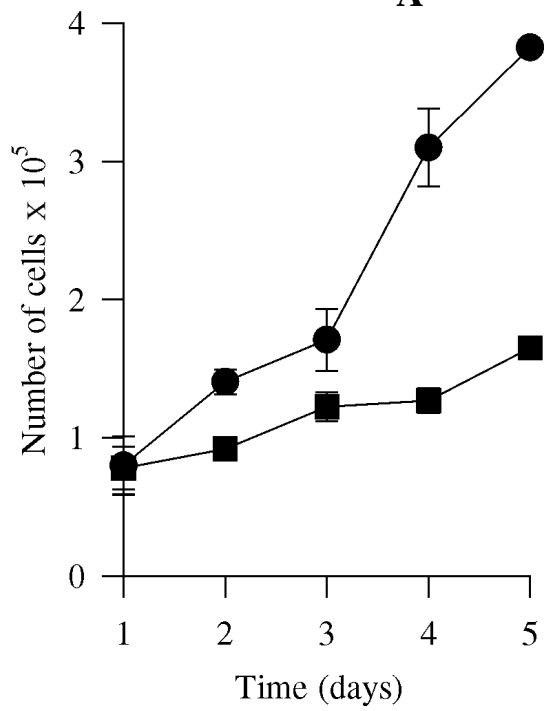

B

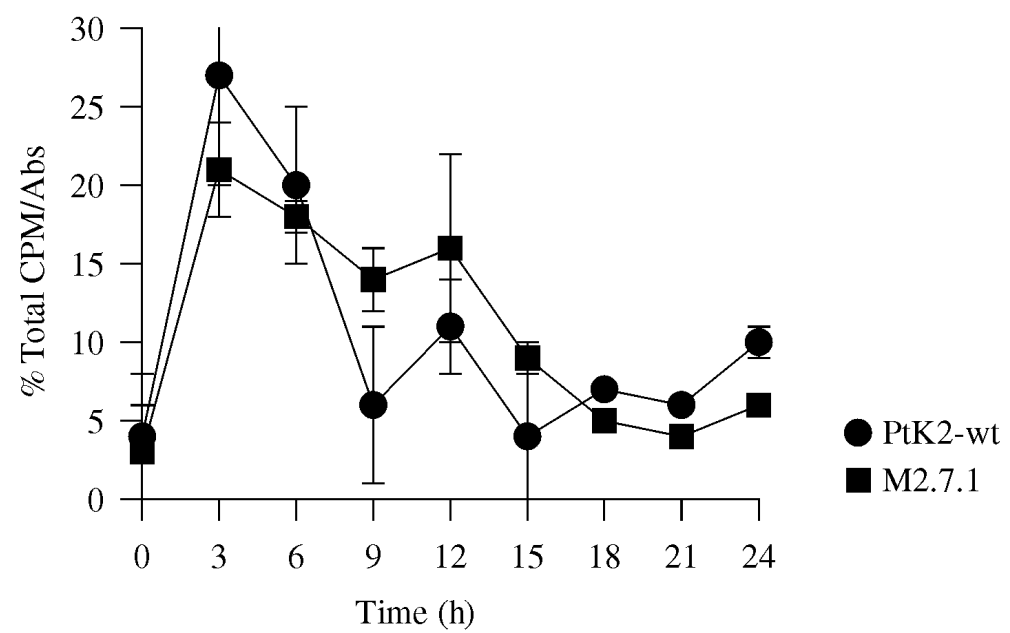

Figure 4 - Cell proliferation in PtK2 (circles) and M2.7.1 (squares) cells. A: Growth rate analysis - cells were plated (10 cells/plate) and cell number determined after indicated time. B: Synchronized cells as described in Material and Methods were pulse-labeled for 30 min and harvested at indicated times, for measurements of nucleotide incorporation in DNA during S-phase. 
toreactivating light, confirming a report by Mitchell et al. (1990), who found that marsupial cells (Monodelphis domestica) were able to photorepair (6-4)PPs, possibly resulting from enhanced repair of these lesions after CPD elimination. However, recent data point to the existence of specific photolyases to (6-4)PPs in Drosophila (Todo et al., 1993), plants (Nakajima et al., 1998) and even in Xenopus cells (Hitomi et al., 1997). Thus, the results shown in this study may be due to (6-4)PP photolyases also present in marsupial cells.

Detection of alterations in both repair capability and the cell cycle agrees with the present notion that several key mechanisms in cell metabolism, such as transcription, repair, cell cycle control and apoptosis, can be linked. The transcription factor TFIIH has been shown to consist of at least nine subunits, including XPB and XPD, involved in nucleotide excision repair (Schaeffer et al., 1993, 1994), and a cdk-activating kinase complex (CAK) involved in cell cycle regulation (Adamczewski et al., 1996). Furthermore, CAK seems to be integrated within TFIIH via association with XPB and XPD (Rossignol et al., 1997). XPB binding to $P 53$, which is involved in induction of cell cycle arrest and apoptosis after DNA damage, has also been shown (Wang et al., 1996). Although current knowledge of these mechanisms in rat kangaroo cells is scarce, they may be similar to what is observed in human and rodent cells. Thus, alterations detected in M2.7.1 in nucleotide excision repair and cell proliferation could mean there is linkage in the control of key mechanisms in cell metabolism.

\section{ACKNOWLEDGMENTS}

Research supported by Fundação de Amparo à Pesquisa do Estado de São Paulo (FAPESP). E.N.M. was the recipient of a $\mathrm{PhD}$ fellowship from $\mathrm{CNPq}$ (Brasília, Brazil). Publication supported by FAPESP.

\section{RESUMO}

Uma linhagem mutante de células de rato-canguru (PtK2) com aumento de sensibilidade à luz ultravioleta (UV) foi isolada a partir de um sistema de seleção positiva. A caracterização desta linhagem indicou que tanto a síntese translesão como o reparoexcisão das lesões mais freqüentemente induzidas por UV, dímeros de pirimidina e (6-4) pirimidina-pirimidonas, encontram-se em níveis normais. No entanto, esta linhagem apresenta uma redução no nível de incisões logo após a indução das lesões, o que poderia representar um defeito no reparo preferencial de genes ativos. Alterações na proliferação celular, com uma fase $\mathrm{S}$ mais longa, também foram detectadas. Este fenótipo reforça a idéia de que mecanismos de controle do metabolismo celular, como ciclo celular, reparo, transcrição e morte celular, estão interligados.

\section{REFERENCES}

Adamczewski, J.P., Rossignol, M., Tassan, J.-P., Nigg, E.A., Moncollin, V. and Egly, J.-M. (1996). MAT1, cdk7 and cyclin H form a kinase complex which is UV light-sensitive upon association with TFIIH. EMBO
J. 15: 1877-1884

Bohr, V.A., Okumoto, D.S. and Hanawalt, P.C. (1986). Survival of UV-irradiated mammalian cells correlates with efficient DNA repair in an essential gene. Proc. Natl. Acad. Sci. USA 83: 3830-3833.

Chiang, T. and Rupert, C.S. (1979). Action spectrum for photoreactivation of ultraviolet-irradiated marsupial cells in tissue culture. Photochem. Photobiol. 30: 525-528.

Collins, A.R.S. (1993). Mutant rodent cell lines sensitive to UV, ionizing radiation and cross linking agents: a comprehensive survey of genetic and biochemical characterization. Mutat. Res. DNA Repair 293: 99-118.

Hitomi, K., Kim, S.T., Iwai, S., Harima, N., Otoshi, E., Ikenaga, M. and Todo, T. (1997). Binding and catalytic properties of Xenopus (6-4) photolyase. J. Biol. Chem. 272: 32591-32598.

Hunter, T. (1993). Breaking the cycle. Cell 75: 839-841.

Menck, C.F.M. and Meneghini, R. (1982). Resistance of 3T3 mouse cells to UV light in relation to excision and transfer of dimers to daughter strands. Photochem. Photobiol. 35: 507-513.

Mezzina, M., Eveno, E., Chevallier-Lagente, O., Benoit, A., Carreau, M., Vermeulen,W., Hoeijmakers, J.H., Stefanini, M., Lehmann, A.R., Weber, C.A. and Sarasin, A. (1994). Correction by the ERCC2 gene of UV sensitivity and repair deficiency phenotype in a subset of trichothiodystrophy cells. Carcinogenesis 15: 1493-1498.

Mitchell, D.L., Applegate, L.A., Nairn, R.S. and Ley, R.D. (1990). Photoreactivation of cyclobutane dimers and (6-4) photoproducts in the epidermis of the marsupial, Monodelphis domestica. Photochem. Photobiol. 51:653-658.

Miyaji, E.N. and Menck, C.F.M. (1995). Ultraviolet-induced cell death is independent of DNA replication in rat kangaroo cells. Photochem. Photobiol. 61: 454-458.

Miyaji, E.N. and Menck, C.F.M. (1996). Photoreversion of ultraviolet induced apoptosis in rat kangaroo cells. Apoptosis 1: 153-160.

Miyaji, E.N. and Menck, C.F.M. (1998). Human Bcl-2 expression delays ultraviolet-induced apoptosis in marsupial cells. Photochem. Photobiol. 68: 719-724.

Nakajima, S., Sugiyama, M., Iwai, S., Hitomi, K., Otoshi, E., Kim, S.T., Jiang, C.Z., Todo, T., Britt, A.B. and Yamamoto, K. (1998). Cloning and characterization of a gene (UVR3) required for photorepair of 6-4 photoproducts in Arabidopsis thaliana. Nucleic Acids Res. 26: 638-644.

Pillidge, L., Downes, C.S. and Johnson, R.T. (1986). Defective post-replication recovery and UV sensitivity in a simian virus 40-transformed Indian muntjac cell line. Int. J. Radiat. Biol. 50: 119-136.

Rosenstein, B. and Ohlsson-Wilhelm, B.M. (1979). Isolation of UV-sensitive clones from a haploid frog cell line. Somatic Cell. Genet. 5: 117-128.

Rossignol, M., Kolb-Cheynel, I. and Egly, J.-M. (1997). Substrate specificity of the cdk-activating kinase (CAK) is altered upon association with TFIIH. EMBO J. 16: 1628-1637.

Schaeffer, L., Roy, R., Humbert, S., Moncollin, V., Vermeulen, W., Hoeijmakers, J.H.J., Chambon, P. and Egly, J.-M. (1993). DNA repair helicase: a component of BTF2 (TFIIH) basic transcription factor. Science 260: 58-63.

Schaeffer, L., Moncollin, V., Roy, R., Staub, A., Mezzina, M., Sarasin, A., Weeda, G., Hoeijmakers, J.H.J. and Egly, J.-M. (1994). The ERCC2/ DNA repair protein is associated with the class II BTF2/TFIIH transcription factor. EMBO J. 13: 2388-2392.

Seroz T., Hwang, J.R., Moncollin, V. and Egly, J.M. (1995). TFIIH: a link between transcription, DNA repair and cell cycle regulation. Curr. Opin. Genet. Dev. 5: 217-221.

Squires, S., Johnson, R.T. and Collins, A.R.S. (1982). Initial rates of DNA incision in UV-irradiated human cells. Mutat. Res. 95: 389-404.

Steller, H. (1995). Mechanisms and genes of cellular suicide. Science 267: 1445-1449.

Todo, T., Takemori, H., Ryo, H., Ihara, M., Matsunaga, T., Nikaido, O., Sato, K. and Nomura, T.A. (1993). A new photoreactivating enzyme that specifically repairs ultraviolet light-induced (6-4) photoproducts. Nature 361:371-374.

Wang, X.W., Vermeulen, W., Coursen, J.D., Gibson, M., Lupold, S.E., Forrester, K., Xu, G., Elmore, L., Yeh, H., Hoeijmakers, J.H.J. and Harris, C.C. (1996). The XPB and XPD DNA helicases are components of the p53-mediated apoptosis pathway. Genes Dev. 10: 1219-1232. 